\title{
Turkey's Warm Welcome of Kosovar Refugees
}

\author{
Frances Trix
}

\begin{abstract}
Turkey's immediate and ongoing acceptance of Kosovar refugees stands out among NATO nations. This article investigates the cultural and historical bonds between Kosovar Albanians and Turks, the widespread and active support for the refugees in Turkish society, and the precedent of three earlier waves of Kosovar refugees who settled in Turkey earlier in the 20th century. It notes the problem of dealing only with humanitarian concerns while ignoring the political causes of refugee flows.
\end{abstract}

\section{Resumé}

La Turquiese démarquenettement au sein des pays de l'OTAN pour son attitude d'ouverture et d'acceptation immédiate et continue a l'égard des réfugiés kosovars. Le présent article étudie les raccords historiques et culturels quilient les albanais kosooars et les turcs, analyse le phénomène général du soutien profond et étendu pour les réfugiés semanifestant dans la société turque, et décrit le précédent que constitue la série de trois vagues de réfugiés kosovars qui s'installèrent en Turquie plus tôt au vingtieme siècle. On met icien reliefle probleme posé par le fait dene tenir compteque des questions strictement humanitaires, sans s'aviser des profondes cause politiques ayant engendré le flot de réfugiés.

\section{Introduction}

Turkey was the first country to voluntarily welcome Kosovar refugees during the current crisis. This early and ongoing reception of Kosovar refugees has

Frances Trix, Ph.D., is a linguistic anthropologist specializing in Turkish, Albanian, Balkan Islam, and immigrant communities. She received her doctorate in linguistics from the University of Michigan, and has also studied at the University of Prishtina in Kosooo and conducted research in the Balkans. She is currently Associate Professor of Anthropology at Wayne State University in Detroit, Michigan, USA been under-reported in Canadian and American media, although it has been cited somewhat more frequently in European media.Specifically, from March 23-26, over 2,000 Kosovar refugees entered Turkey. Onemonthlater, by April 27 , over 12,000 Kosovar refugees had come to Turkey, of whom 4,400 were housed in the Gaziosmanpasha refugee centre outside Edime in European Turkey. By May 25, there were 16,500 Kosovar refugees in Turkey, of whom 7,000 reside at the Gaziosmanpasha centre. ${ }^{1}$ Besides refugees on Turkish soil, Turkey's Kizilay (Red Crescent) also supports and runs two refugee camps closer to Kosovo: one in Elbasan, Albania; the other, the Bojane Camp, in Macedonia. Of all the NATOcountries, Turkey has taken in the highest number of refugees. Why has Turkey responded to the crisis in Kosovo so generously?

In this short paper I will document the variety of ways the Kosovar refugees have been supported by Turkey. I will also contextualize the current wave of Kosovar refugees as just one in four waves of Kosovar Albanians forced to emigrate from Kosovo this century, the majority of whom settled in Turkey. Indeed, the presence in Turkey of four generations of Albanians, all of whom left Kosovo under duress, documents Serbia's ongoing policy to expel Albanians fromKosovo.

\section{Common Bond and Support for Kosovar Refugees in Turkish Society}

Articles in the Turkish press frequently note the cultural and historical bonds that the Kosovar refugees share with the Turks. This refers to their common religious affiliation-most Kosovar Albanians and Turks are Muslims. It also refers to the long period, from the fourteenth century to the twentieth century, when Kosovo and Turkey were part of the Ottoman Empire. Further, many older Kosovars still speak some Turk- ish; while younger Kosovars, principally from the Prizren region, also speak Turkish. Besides religion, history, and somelanguage, the Kosovar Albanians and Turks share a patriarchal, patrilocal social structure as well as many customs of daily life. For example, the daily ration at the Gaziosmanpasha refugee centre always includes yogurt-a food common to both Turks and Kosovars, but less likely to be found in the food aid from other NATO countries.

Turkish support for the Kosovar refugees has been expressed from the highest levels of political power across society. ${ }^{2}$ Within the first week of the crisis the Turkish Cabinet agreed to accept 20,000 refugees. The Minister of the Interior was appointed to head the board to coordinate refugee relief. Prime Minister Ecevithimself donated one billion Turkish lira as a model for other political leaders, and President Demirel's visit to refugee camps in Albania and Macedonia on April 11 was the first such visit of a head of state. Business institutions also donated large sums of money or goods toward refugee relief. These included major banks (IB Bank, Central Bank), the Union of Turkish Chambers and Commodities Exchange (TOBB), the Koç Conglomerate, and a major textile manufacturer (EGS), among others. Municipalities, including Ankara and Istanbul, conducted campaigns to raise funds, as have Turkish Radio and Television (TRT). State Theatres donated receipts from over one hundred performances; "Contemporary Turkish Artists" donated their income from the main May exhibit in Istanbul; and Bilkent University collected clothing and supported education in the camps. In the provinces there. has also been widespread support. For example, employees of national education in Isparta collected funds to support schooling in the camps, while the police officers in Tekirdag sentclothing. This spring, at the time of the main

Refuge, Vol. 18, No. 3 (August 1999) 
1.

Muslim holiday, many ordinary Turks sent the money they annually give for zekat or" alms" (one of the five pillars of Islam) to Kosovar refugee relief. ${ }^{3}$

\section{Waves of Forced Emigration of Kosovar Albanians across the 20th Century}

During the First Balkan War in 1912, Serbia occupied Kosovo which was then still part of the Ottoman Empire. To strengthen its demographic claim to the region, Serbia engaged in massacres of Albanians in the region's main cities (a Danish journalist reported 5,000 Albanians killed in Prishtina after its capture).4 From 1912-1915, over 100,000 Kosovar Albanians fled Kosovo, with many eventually settling in Turkey.

The second wave of forced emigration of Kosovar Albanians took place between 1918-1939. The Great Powers gave Kosovo to Serbia in 1918, with the . agreement in 1919 that minorities would be protected. Serbia immediately began a program of harassment of Kosovar Albanians: closing Albanian schools, expropriating cemeteries and mosques, seizing Albanians'lands, followed by the colonization of Kosovo by Montenegrins from the west and Serbs from the north. During this period, half the arable land in Kosova was confiscated by the government. In fear, and deprived of their land, many Kosovars emigrated to Turkey. For example, from 1924-1926, 32,000 Albanians emigrated to Turkey from Kosovo. ${ }^{5}$ All told, around 120,000 Kosovars left Kosovo between 19181939, with many ending up in Turkey.

Revealing of Serbian policy at this time was a government plan for many more to leave. In 1938, Serbia planned and contracted with Turkey to take 40,000 families from Kosovo. A fabrication was that all these families were Turks. The specification of "family" was used to refer to all those living under one roof. With the extended families of Kosovar Albanians, this would have signified at least ten people per family, for a total of 400,000 to be expelled. ${ }^{6}$ World War II intervened so the plan was not carried out.
The third wave of Albanian emigration to Turkey from Kosovo took place after World War II, from 1953 to 1966. Kosovar Albanians had not supported Tito's Partisans during the war, and they were not attracted to communism, with its anti-religious policies and collectivization programs, after the war. Rankovic, close friend of Tito and known for his anti-Albanian stance, was in power until 1966. Kosovar Albanians were encouraged to register as "Turks," which many interpreted as "Muslim." Then, as "Turks," they were harassed and encouraged to emigrate to Turkey. At least 100,000 did so during this time. ${ }^{7}$ The fourth wave is of course the expulsions of the spring of 1999. To date, over 900,000 Kosovar Albanians have been expelled from Kosovo, with another 300,000 internally displaced, and unknown numbers killed.

\section{Conclusion}

Thanks to these waves of forced emigration, there are numerous people in Turkey of Kosovar Albanian descent. Many of these people have taken Kosovar refugees, who are relatives or distant relatives or frie1'1ds, into their homes. Thus, of the 16,000 Kosovar refugees in Turkey at the end of May, 1999, more than half were not in the refugee centre. Instead they were principally in Istanbul, Tekirdag, Yalova and Bursa-cities where there are sizeable numbers of people of Albanian descent. Besides a common Islamic and Ottoman heritage, these people also share more recent experiences of political oppression in the Balkans.

Compound the common cultural heritage and historical experience with the high value placed on hospitality in Turkish culture, the supportive action of Turkey' s leaders, and the presence of other Albanians, and it is not hard to understand the warm welcome the Kosovar refugees received in Turkey. Behind this, though, the Kosovar Albanians in Turkey represent four generations of loss and the sadness and trauma that often accompany forced emigration. As with the recent Bosnian experience, 8 the repeated waves of Kosovar refugees to Turkey reflect what happens when only immediate humanitarian crises have been dealt with, while the political policy that periodically cre- . ated large numbers of refugees was left unchallenged.m

\section{Notes}

1. Statistics come from Turkish press, corroborated by Reuters.

2. The following examples of support in Turkish society were culled from major Turkish newspapers (Milliyet, Akflam, Cumhurriyet, Sabah, Hiirriyet, The Turkish Times) in March, April, and May of 1999.

3. Special thanks to Feyza Sayman for weekl y discussions of Turkish language and society.

4. Noel Malcolm, A Short History of Kosovo (New York: New York University Press, 1998), 253.

5. Ibid., 286. See also 278-86 for discussion of colonization.

6. "Convention regulating the emigra tion of the Turkish population from the region of southern Serbia in Yugoslavia, 1938," in Kosovo: In the Heart of the Powder Keg, edited by Robert Elsie (Boulder, CO: East European Monographs, 1997), 425-34.

7. Malcolm, A Short History of Kosovo, 323.

8. Thomas G. Weiss, and Amir Pasic, "Dealing with the Displacement and Suffering Caused by Yugoslavia's Wars," in The Forsaken People: Case Studies of the Internally Displaced, edited by Roberta Cohen and Francis Deng (Washington, DC: Brookings Institution Press, 1998), 222. a

Refuge, Vol. 18, No.3 (August 1999)
Centre for Refugee Studies ON-Line

WebSite: http://www.yorku.ca/research/crs

$$
\text { Email: refuge@yorku.ca }
$$

